\title{
AKTSAR
}

ISSN 2622-5255 (online)

Volume 2 Nomor 2, Desember 2019, Halaman 233-248

ISSN 2622-2345 (cetak)

\section{Pengungkapan Islamic Social Reporting: Pengaruh Profitabilitas, Leverage, dan Kinerja Lingkungan (Studi Empiris pada Perusahaan yang Terdaftar di JII Tahun 2013-2017)}

\author{
Nawang Kalbuana \\ Politeknik Penerbangan Indonesia Curug \\ nawang.kalbuana@stpicurug.ac.id \\ Marista Winanti Sutadipraja \\ Institut Teknologi dan Bisnis Ahmad Dahlan Jakarta \\ maristasutadipraja@gmail.com \\ Titik Purwanti \\ Universitas Widya Dharma Klaten \\ titik@unwidha.ac.id \\ Dwi Santoso \\ Institut Teknologi dan Bisnis Ahmad Dahlan Jakarta \\ dwisantoso.8888@gmail.com
}

\begin{abstract}
The purpose of this study is to analyze the effect of profitability, leverage and environmental performance on ISR disclosures on companies listed in the Jakarta Islamic Index (JII) during 2013-2017. In this study, the magnitude of the ISR disclosure score that is filled with a company is obtained through annual reports using the content analysis method. Samples were selected by purposive sampling method. While hypothesis testing uses the method of multiple linear regression analysis. The results of this study indicate that the variable profitability, leverage, and environmental performance simultaneously have a significant effect on ISR disclosure. While partially, profitability has no effect on ISR disclosure. Environmental performance and leverage have a positive and significant effect on ISR disclosure. The implications of this study are expected to be able to provide theoretical contributions related to the disclosure of Islamic social responsibility and practically useful to provide input to policymakers and regulators on the Indonesia Stock Exchange.
\end{abstract}

Keywords: Profitability; Leverage; Environmental Performance; Islamic Social Reporting 


\begin{abstract}
ABSTRAK
Tujuan penelitian ini untuk menganalisa pengaruh profitabilitas, leverage dan kinerja lingkungan terhadap pengungkapan ISR pada perusahaan yang terdaftar di Jakarta Islamic Index (JII) selama tahun 2013-2017. Dalam penelitian ini besarnya skor pengungkapan ISR yang dipenuhi suatu perusahaan diperoleh melalui laporan tahunan dengan menggunakan metode analisis isi. Sampel dipilih dengan metode purposive sampling. Sedangkan pengujian hipotesis menggunakan metode analisis regresi linear berganda. Hasil penelitian ini menunjukkan bahwa variabel profitabilitas, leverage dan kinerja lingkungan secara simultan berpengaruh signifikan terhadap pengungkapan ISR. Sedangkan secara parsial, profitabilitas tidak berpengaruh terhadap pengungkapan ISR. Kinerja lingkungan dan leverage berpengaruh positif dan signifikan terhadap pengungkapan ISR. Implikasi penelitian ini diharapkan mampu memberikan kontribusi teoritis berkaitan dengan pengungkapan tanggung jawab sosial Islam dan secara praktis bermanfaat memberikan masukan bagi para pengambil kebijakan dan regulator di Bursa Efek Indonesia.
\end{abstract}

Kata kunci: Profitability; Leverage; Environmental Performance; Islamic Social Reporting

\title{
PENDAHULUAN
}

Isu mengenai tanggung jawab sosial perusahaan atau CSR (Corporate Social Responsibility) semakin menjadi sorotan penting dalam beberapa tahun terakhir karena konsep CSR merupakan inti dari etika bisnis perusahaan. Tujuan utama CSR adalah menjadikan perusahaan bukan hanya pada konsep single-bottom-line (SBL) dalam suatu catatan keuangan perusahaan, tetapi juga pada konsep triple-bottom-line (TBL) yang mencakup aspek keuangan, kehidupan sosial serta lingkungan hidup (Faricha, 2015).

Kini konsep CSR tidak hanya ada di ekonomi konvensional. Tetapi juga berkembang dalam ekonomi yang berbasis islam. CSR dalam islam erat kaitannya dengan perusahaan yang menjalankan kegiatan perusahaan yang sesuai dengan konsep syariah. Selama ini, penelitian yang dilakukan mengenai pelaksanaan ISR berorientasi pada sektor perbankan syariah saja, sedangkan pada sektor non perbankan dan lembaga keuangan lainnya seperti pada pasar modal, penelitian yang dilakukan mengenai ISR belum banyak dilakukan sehingga kurangnya informasi mengenai konsep ISR terutama di Indonesia. Padahal sudah banyak indeks-indeks syariah yang terdapat di BEI (Faricha, 2015).

Salah satu produk pasar modal syariah di Indonesia saat ini adalah Jakarta Islamic Index (selanjutnya disebut sebagai JII). Saham-saham syariah yang masuk 
dalam JII merupakan saham yang sudah lolos melalui proses penyeleksian oleh Bursa Efek Indonesia (BEI). Saham syariah yang menjadi konstituen JII terdiri dari 30 saham yang merupakan saham-saham syariah paling likuid dan memiliki kapitalisasi pasar yang besar. BEI melakukan review JII setiap 6 bulan, yang disesuaikan dengan periode penerbitan Daftar Efek Syariah (selanjutnya disebut sebagai DES) oleh Otoritas Jasa keuangan (OJK). Setelah dilakukan penyeleksian saham syariah oleh OJK yang dituangkan ke dalam DES, BEI melakukan proses seleksi lanjutan yang didasarkan kepada kinerja perdagangannya (www.idx.co.id).

Kerangka pelaporan tanggung jawab sosial perusahaan yang sesuai dengan prinsip-prinsip syariah dikenal dengan Islamic Social Reporting (ISR). ISR pertama diperkenalkan oleh Prof. Roszaini Haniffa pada tahun 2002 melalui jurnal yang berjudul Social Reporting Disclosure An Islamic Perspective. Selanjutnya penelitian tersebut dikembangkan oleh Othman dkk pada tahun 2009 melalui jurnal yang berjudul Determinants of Islamic Social Reporting Among Top Shariah-Approved Companies in Bursa Malaysia. Di Indonesia, belum terdapat aturan yang jelas mengenai pengungkapan ISR di kalangan perusahaan. Oleh karena itu, dibutuhkan acuan untuk mengukur kinerja lembaga dan/atau institusi syariah dalam membuat laporan tanggung jawab sosial yang turut menyajikan aspek-aspek religi. Termasuk diantaranya adalah perusahaan-perusahaan yang terdaftar di JII (Astuti, 2013).

Dari penelitian-penelitian sebelumnya ditemukan beberapa faktor yang mempengaruhi tingkat pengungkapan ISR. Salah satu faktor yang mempengaruhi pengungkapan ISR adalah profitabilitas. Penelitian yang dilakukan Anggraini dan Wulan (2015) dan Maulida dkk. (2014) menyatakan bahwa profitabilitas berpengaruh signifikan terhadap pengungkapan ISR. Menurut Rahayu (2018), Hartawati dkk. (2017), Dhiyaul-Haq dan Santoso (2016), Rosiana dkk. (2015), Faricha (2015), dan Astuti (2013) profitabilitas tidak berpengaruh terhadap pengungkapan ISR.

Leverage mempengaruhi pengungkapan ISR sesuai penelitian Anggraini dan Wulan (2015), menyatakan bahwa leverage berpengaruh signifikan terhadap pengungkapan ISR, hal ini berbanding terbalik dengan penelitian Rosiana dkk. (2015) dan Astuti (2013) yang menyatakan leverage tidak berpengaruh terhadap pengungkapan ISR.

Kinerja lingkungan juga mempengaruhi pengungkapan ISR sesuai penelitian Maulida dkk. (2014) menyatakan bahwa kinerja lingkungan berpengaruh signifikan terhadap pengungkapan ISR. Lain halnya dengan penelitian Rahayu (2018) dan Hartawati et al (2017) yang menganalisis pengaruh kinerja lingkungan tidak memiliki pengaruh yang signifikan terhadap pengungkapan ISR.

Berdasarkan permasalahan yang dikemukakan diatas, dapat diajukan pertanyaan penelitian apakah profitabilitas, leverage dan kinerja lingkungan berpengaruh terhadap pengungkapan ISR?

Adapun yang menjadi tujuan dari penelitian ini guna memperoleh bukti empiris tentang pengaruh dari profitabilitas, leverage dan kinerja lingkungan terhadap pengungkapan Islamic Social Reporting pada perusahaan Jakarta Islamic Index (JII) yang terdaftar di Bursa Efek Indonesia. 


\section{TINJAUAN LITERATUR}

\section{Teori Legitimasi (Legitimacy Theory)}

Dalam teori ini, perusahaan akan melakukan aktivitas CSR disebabkan adanya tekanan sosial, politik dan ekonomi dari luar perusahaan. Sehingga perusahaan akan menyeimbangkan tuntutan tersebut dengan melakukan apa yang diinginkan oleh masyarakat dan apa yang diharuskan oleh peraturan. Teori ini mengungkapkan bahwa perusahaan secara kontinyu berusaha untuk bertindak sesuai dengan batasbatas dan norma-norma dalam masyarakat. Atas usahanya tersebut perusahaan berusaha agar aktivitasnya diterima menurut persepsi pihak eksternal (Deegan, 2000).

Sebuah perusahaan melegitimasi keberadaannya dalam masyarakat jika operasi dan kegiatannya terlihat mengikuti norma-norma yang disetujui oleh masyarakat. Jika suatu perusahaan dipandang tidak mengikuti norma-norma sosial yang diharapkan dalam operasinya, maka akan ada kesenjangan legitimasi antara operasi perusahaan dan harapan masyarakat. Dalam hal CSR, perusahaan bisa melegitimasi operasi mereka dengan memiliki praktik CSR yang baik. Salah satu cara untuk menggambarkan praktik CSR yang baik adalah dengan mendapat penghargaan atas praktik CSR. Jika suatu perusahaan mendapat penghargaan atas praktik CSR yang baik, maka kesenjangan legitimasi antara perusahaan dan masyarakat akan sangat kecil, dan perusahaan lebih bersedia untuk menjadi lebih transparan (Dhiyaul-Haq dan Santoso, 2016).

\section{Hipotesis}

Hipotesis penelitian dapat dirumuskan sebagai berikut :

$\mathrm{H}_{1} \quad$ : Profitabilitas, leverage dan kinerja lingkungan secara simultan berpengaruh signifikan terhadap pengungkapan ISR

$\mathrm{H}_{2} \quad$ : Profitabilitas berpengaruh positif signifikan terhadap pengungkapan ISR

$\mathrm{H}_{3}$ : Leverage berpengaruh positif signifikan terhadap pengungkapan ISR

$\mathrm{H}_{4} \quad$ : Kinerja lingkungan berpengaruh positif signifikan terhadap pengungkapan ISR

Kerangka hipotesis penelitian dapat dilihat pada Gambar 1 sebagai berikut:

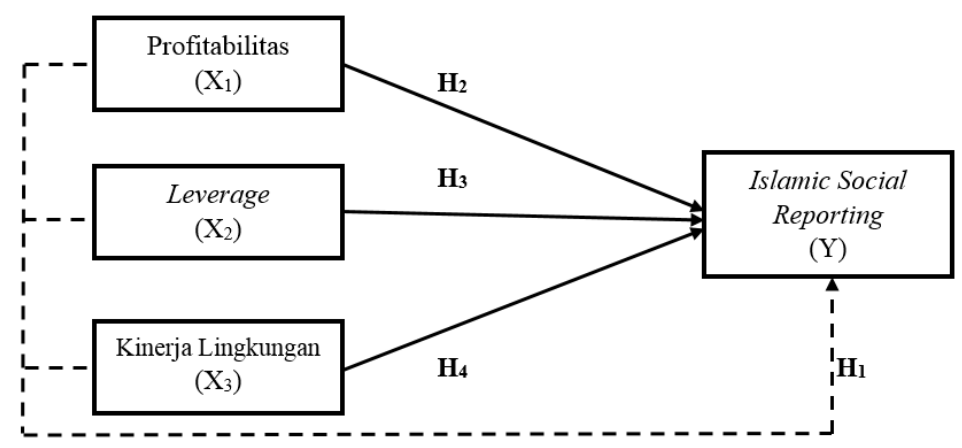

Gambar 1. Kerangka Hipotesis Penelitian 


\section{METODE}

\section{Metode Penelitian}

Penelitian ini menggunakan data sekunder berupa laporan tahunan (annual report), laporan keuangan (financial report) dan hasil publikasi Program Penilaian Kinerja Perusahaan dalam Pengelolaan Lingkungan Hidup (PROPER) yang diterbitkan oleh Kementerian Lingkungan Hidup (KLH) dan perusahaan yang terdaftar di Jakarta Islamic Index (JII) pada Bursa Efek Indonesia periode 2013-2017. Adapun data tersebut diperoleh dari melalui akses website masing-masing perusahaan yang terdaftar di JII dan website Kementerian Lingkungan Hidup (KLH).

Populasi dalam penelitian ini adalah perusahaan yang terdaftar di JII pada Bursa Efek Indonesia berjumlah 30 perusahaan. Pemilihan sampel menggunakan teknik purposive sampling. Kriteria sampel dalam penelitian ini yaitu : 1)Perusahaan yang konsisten terdaftar di JII selama periode 2013-2017, 2) Perusahaan yang konsisten mengikuti PROPER selama periode 2013-2017, 3) Perusahaan yang menggunakan mata uang rupiah. Sampel yang didapatkan adalah 9 perusahaan dengan periode 2013-2017 sehingga total data sampel sebanyak 45 data.

\section{Definisi Operasional Variabel}

\section{Profitabilitas (X1)}

Profitabilitas adalah kemampuan suatu perusahaan untuk memperoleh keuntungan. Profitabilitas dalam penelitian ini diukur dengan menggunakan Return on Assets (ROA). ROA berfungsi untuk mengukur efektifitas perusahaan dalam menghasilkan laba dengan memanfaatkan aktiva yang dimilikinya (Astuti, 2013). ROA dapat dihitung dengan rumus berikut ini:

$$
\frac{\text { Laba Setelah Pajak }}{\text { Total Aset }}
$$

\section{Leverage (X2)}

Leverage perusahaan pada penelitian ini, diukur dengan nilai Debt to Equity Ratio (DER). DER merupakan rasio untuk mengukur tingkat hutang suatu perusahaan. DER menggambarkan tingkat penggunaan hutang terhadap jumlah ekuitas perusahaan. Disamping itu, DER juga dapat digunakan untuk mengukur kemampuan perusahaan dalam membayar hutang dalam jangka panjang (Anggraini dan Wulan, 2015). DER dapat dihitung dengan rumus berikut ini:

$$
\text { DER }=\frac{\text { Total Hutang }}{\text { Total Ekuitas }}
$$

\section{Kinerja Lingkungan (X3)}

Pengukuran kinerja lingkungan dalam penelitian ini dengan melihat prestasi perusahaan dalam mengikuti Program Penilaian Kinerja Perusahaan dalam Pengelolaan Lingkungan Hidup (PROPER). Pemeringkatan PROPER tersebut menggunakan lima warna sebagai nilai (skor) masing-masing perusahaan (Hartawati 
dkk., 2017). Skor PROPER ini diperoleh dari press PROPER yang diumumkan secara rutin oleh Kementerian Lingkungan Hidup (KLH). Sistem peringkat kinerja PROPER mencakup pemeringkatan perusahaan dalam lima (5) warna yakni:

Emas : Sangat-sangat baik skor $=5$

Hijau : Sangat baik skor $=4$

Biru : Baik skor $=3$

Merah: Buruk skor $=2$

Hitam: Sangat buruk skor $=1$

\section{Islamic Social Reporting (Y)}

Variabel dependen dalam penelitian ini adalah tingkat pengungkapan tanggung jawab sosial secara syariah pada laporan tahunan perusahaan yang diukur dengan nilai (score) dari indeks Islamic Social Reporting (ISR). Indeks ISR dalam penelitian ini adalah indeks yang diadopsi dari penelitian Faricha (2015) dan Maulida dkk. (2014) dengan beberapa modifikasi sesuai penelitian. Peneliti melakukan analisis secara keseluruhan (content analysis) terhadap laporan tahunan masing-masing perusahaan, analisis ini dengan metode skoring berdasarkan Islamic Social Reporting (ISR) indeks yang terdiri dari 6 tema yaitu tema pendanaan dan investasi, produk dan jasa, karyawan, sosial masyarakat, lingkungan dan tata kelola perusahaan. Tema tersebut dikembangkan menjadi 48 item pernyataan. Metode penilaian (scoring) untuk setiap item tersebut adalah sebagai berikut:

Nilai 0 untuk setiap item yang tidak diungkapkan

- $\quad$ Nilai 1 untuk setiap item yang diungkapkan

Selanjutnya pengukuran indeks ISR setelah skoring dilakukan dengan rumus sebagai berikut :

$$
\begin{aligned}
& \text { Jumlah skor disclosure } \\
& \text { Jumlah skor maksimum }
\end{aligned}
$$

\section{Metode Analisis Data}

Teknik pengujian hipotesis dalam penelitian ini adalah analisis regresi linear berganda. Model regresi yang baik harus memiliki distribusi data normal dan bebas dari asumsi klasik. Sehingga sebelum dilakukan analisis regresi, terlebih dahulu dilakukan uji asumsi klasik meliputi uji normalitas, uji multikolonieritas, uji heteroskedastisitas dan uji autokorelasi. Uji hipotesis yang digunakan meliputi uji $t$, uji F, dan koefisien determinasi. Persamaan regresi linear berganda dalam penelitian ini sebagai berikut :

$\begin{array}{lll}\mathbf{Y =} \mathbf{a}+\boldsymbol{\beta} \mathbf{X}_{\mathbf{1}}+\boldsymbol{\beta} \mathbf{X}_{\mathbf{2}}+\boldsymbol{\beta} \mathbf{X}_{\mathbf{3}}+\mathbf{e} \\ \text { Keterangan : } \\ \mathrm{Y} \quad= & \text { Pengungkapan ISR } \\ \mathrm{a} & = & \text { Konstanta } \\ \beta & = & \text { Koefisien Regresi } \\ \mathrm{X}_{1}= & \text { Profitabilitas } \\ \mathrm{X}_{2}= & \text { Leverage } \\ \mathrm{X}_{3}= & \text { Kinerja Lingkungan } \\ \mathrm{e} & = & \text { Error Term }\end{array}$




\section{HASIL DAN PEMBAHASAN}

\section{Hasil Analisis Isi (Content Analysis) Index ISR}

Hasil content analysis dapat dilihat dari masing-masing tema pengungkapan indeks ISR untuk melihat konsistensi pengungkapan masing-masing tema. Dalam pengungkapan tanggung jawab sosial secara islami menggunakan indeks ISR dengan memperhatikan tema-tema yang disajikan, sehingga setiap perusahaan memiliki konsep yang berbeda-beda dalam mengunggulkan atau concern yang lebih dalam aspek yang akan ditonjolkan perusahaan. Misalnya dalam laporan tahunan, laporan berkelanjutan, press release dan informasi lain yang diterbitkan perusahaan. Indeks ISR terdiri dari enam tema yaitu pembiayaan dan investasi, produk dan jasa, karyawan, masyarakat, lingkungan, tata kelola perusahaan. Berikut adalah perhitungan content analysis berdasarkan tema terhadap sampel tahun 2013-2017.

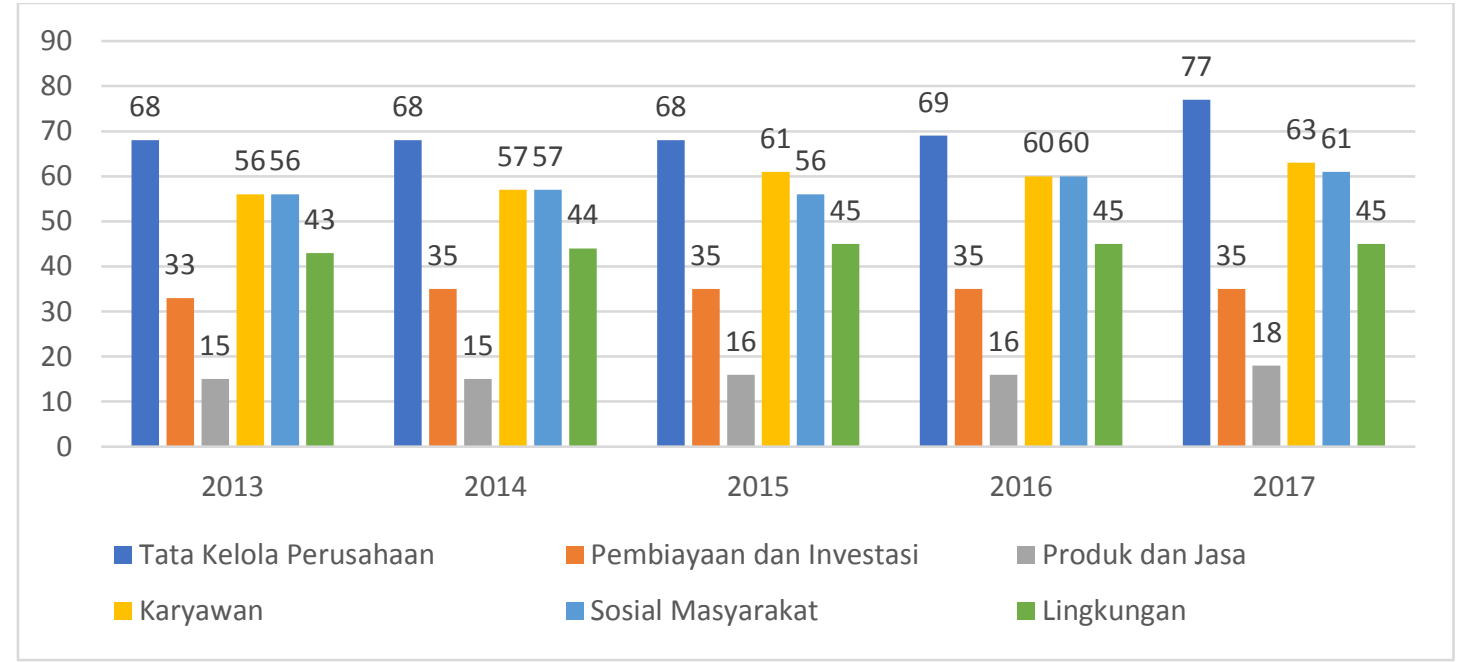

Sumber: data diolah

Gambar 2. Skor Indeks ISR Masing-masing Tema

Gambar 2 memperlihatkan secara umum skor indeks ISR untuk masingmasing tema mengalami pergerakan stagnan dan cenderung meningkat selama tahun 2013-2017, kecuali tema karyawan dan sosial masyarakat yang mengalami ketidakkonsistenan, sebagai contoh item sosial masyarakat dari tahun 2013 mendapatkan 56 pengungkapan, di tahun 2014 mendapatkan 57 pengungkapan, di tahun 2015 mendapatkan 56 pengungkapan, di tahun 2016 dan 2017 meningkat drastis menjadi 60 dan 61 pengungkapan. Walaupun peningkatan tema sosial masyarakat dan karyawan bergerak fluktuatif, hal ini menunjukkan bahwa perusahaan syariah telah melakukan pengungkapan sosial masyarakat dan karyawan dengan sangat baik. Adanya ketidakkonsistenan perusahaan dalam melakukan pelaporan sosial secara islami, menunjukkan bahwa ada perbedaan antara perusahaan yang mengungkapkan secara baik namun ada pula yang sebaliknya. Perbedaan tersebut disebabkan tidak ada standar mengenai pelaksanaan pelaporan sosial secara islami, sehingga pengungkapan menjadi tidak seragam. Pengungkapan tanggung jawab sosial secara islami sendiri masih hanya pengembangan dari 
beberapa peneliti, berisi kompilasi item-item standar CSR yang ditetapkan oleh AAOIFI (Accounting and Auditing Organization for Islamic Financial Institutions).

\section{Hasil Analisis Statistik Deskriptif}

Statistik deskriptif variabel-variabel dalam penelitian ini terlihat dalam Tabel 1 sebagai berikut:

Tabel 1. Statistik Deskriptif

\begin{tabular}{|c|c|c|c|c|c|}
\hline & $\mathrm{N}$ & nimum & Iaximum & Mean & $\begin{array}{c}\text { Std. } \\
\text { Deviation }\end{array}$ \\
\hline Profitabilitas & 45 & 3.23 & 42.14 & 12.7918 & 10.22239 \\
\hline Leverage & 45 & 19.59 & 265.46 & 80.4491 & 64.62590 \\
\hline $\begin{array}{l}\text { Kinerja } \\
\text { Lingkungan }\end{array}$ & 45 & 2 & 5 & 3.31 & .557 \\
\hline $\begin{array}{l}\text { Islamic } \\
\text { Social } \\
\text { Reporting }\end{array}$ & 45 & .54 & .79 & .6544 & .07050 \\
\hline $\begin{array}{ll}\text { Valid } & \mathrm{N} \\
\text { (listwise) } & \end{array}$ & 45 & & & & \\
\hline
\end{tabular}

Sumber: data diolah

Berdasarkan di atas dapat dilihat bahwa angka rata-rata pengungkapan ISR yang dilakukan oleh 9 perusahaan yang konsisten terdaftar di JII selama tahun 20132017 adalah 0,6544 atau sebesar 65,44\%. Hal ini menunjukkan bahwa rata-rata pengungkapan ISR yang dilakukan oleh perusahaan-perusahaan yang dijadikan sampel sudah cukup baik karena nilainya telah mencapai lebih dari setengah total komponen ISR yang menjadi dasar perhitungan indeks ISR pada penelitian ini. Nilai minimumnya sebesar 0,54 . Nilai maksimalnya sebesar 0,79 Sedangkan nilai standar deviasinya sebesar 0,07050.

Variabel bebas pertama, yaitu profitabilitas yang diproksikan oleh ROA memperlihatkan nilai rata-ratanya adalah 12,7918. Hal ini menunjukkan bahwa ratarata perusahaan yang menjadi sampel dalam penelitian ini memiliki kemampuan memperoleh laba sebesar $12,79 \%$ per aset yang dimiliki. Nilai minimumnya adalah $3,23 \%$ dan nilai maksimumnya adalah $42,14 \%$ sedangkan standar deviasinya adalah 10,22. Perbedaan nilai minimum dan maksimum yang cukup jauh pada rasio profitabilitas ini dapat disebabkan oleh kemampuan perusahaan yang berbeda-beda dalam pengolahan aset yang dimilikinya.

Variabel bebas kedua yang digunakan dalam penelitian ini adalah leverage yang diproksikan oleh DER. Nilai rata-rata DER sebesar 80,45\%, nilai minumnya sebesar 19,59\% dan nilai maksimumnya sebesar 265,46\%. Angka yang dihasilkan oleh standar deviasinya adalah 64,63. Nilai rata-rata DER sebesar 80,45\% menandakan bahwa rata-rata perusahaan yang menjadi sampel dalam penelitian ini masih banyak yang menggunakan hutang dalam membiayai perusahaan. Nilai minimum menunjukkan adanya perusahaan yang hanya menggunakan hutang sebesar 19,59\% untuk membiayai perusahaan. Sedangkan nilai maksimum 265,46\% menunjukkan 
adanya perusahaan yang menggunakan hutang relatif tinggi untuk membiayai perusahaan.

Variabel bebas terakhir yang digunakan dalam penelitian ini adalah kinerja lingkungan. Nilai rata-rata kinerja lingkungan sebesar 3,31, nilai minumnya sebesar 2 dan nilai maksimumnya sebesar 5. Angka yang dihasilkan oleh standar deviasinya adalah 0,557. Nilai rata-rata kinerja lingkungan sebesar 3,31 menandakan bahwa ratarata perusahaan yang menjadi sampel dalam penelitian ini sudah mulai melakukan tanggung jawab sosial khususnya di bidang lingkungan untuk menghindari pencemaran lingkungan di sekitar lokasi perusahaan.

\section{Hasil Uji Asumsi Klasik}

Hasil Uji normalitas dilihat dari hasil uji signifikansi Kolmogorov-Smirnov Z.

Tabel 2. Hasil Uji Kolmogorof-Smirnov

\begin{tabular}{|c|c|c|}
\hline & & $\begin{array}{c}\text { Unstandardized } \\
\text { Residual }\end{array}$ \\
\hline $\mathrm{N}$ & & 45 \\
\hline \multirow{2}{*}{$\begin{array}{l}\text { Normal } \\
\text { Parameters }{ }^{\mathrm{a}, \mathrm{b}}\end{array}$} & Mean & $0 \mathrm{E}-7$ \\
\hline & Std. Deviation & .05915133 \\
\hline \multirow{3}{*}{$\begin{array}{l}\text { Most Extreme } \\
\text { Differences }\end{array}$} & Absolute & .083 \\
\hline & Positive & .083 \\
\hline & Negative & -.073 \\
\hline \multicolumn{2}{|c|}{ Kolmogorov-Smirnov Z } & .554 \\
\hline \multicolumn{2}{|c|}{ Asymp. Sig. (2-tailed) } & .918 \\
\hline
\end{tabular}

a. Test distribution is Normal.

Sumber: data diolah

Tabel 2 menunjukkan hasil uji normalitas untuk data yang dianalisis. Uji normalitas dengan menguji normalitas residual dan dapat dilihat melalui nilai Asymp.Sig (2-Tailed) sebesar 0,918 jauh di atas nilai signifikan 0,05. Sehingga dapat disimpulkan bahwa model regresi terdistribusi secara normal.

Hasil uji multikolinearitas menunjukkan bahwa masing-masing variabel mempunyai nilai tolerance lebih dari 0,10 dan nilai variance inflation factor (VIF) kurang dari 10. Nilai tolerance profitabilitas, leverage, dan kinerja lingkungan adalah 0,483, 0,577 , dan 0,779 . Sedangkan nilai VIF 2,071, 1,732, dan 1,183. Dengan demikian, dapat disimpulkan bahwa persamaan regresi tidak terdapat problem multikolinearitas.

Hasil uji autokorelasi dapat dilihat dari nilai Durbin-Watson. Dari hasil SPSS, diperoleh nilai DW sebesar 2,011. Nilai ini kemudian dibandingkan dengan nilai tabel DurbinWatson d statistic: level of significance, untuk jumlah sampel (n) adalah 45 dan jumlah variabel independen $(\mathrm{k}=3)$. Maka nilai DL berada dititik 1,383 dengan DU dititik 1,666. Oleh karena nilai Durbin Watson yang diperoleh dari hasil pengolahan adalah sebesar 2,011 berarti nilainya berada di atas DU $(1,666)$ dan dibawah 4-DL $(2,617)$. Hal ini menunjukkan bahwa model tersebut merupakan model regresi yang baik karena tidak mengandung autokorelasi. 
Hasil uji heteroskedastisitas dilihat melalui grafik scatterplot yang menunjukkan tidak ada pola yang jelas dan titik-titik menyebar di atas dan di bawah angka 0 pada sumbu $Y$. Hal ini dapat disimpulkan bahwa tidak terjadi heteroskedastisitas pada model regresi. Sehingga model regresi layak dipakai untuk memprediksi pengungkapan ISR berdasarkan masukan variabel independen profitabilitas, leverage dan kinerja lingkungan.

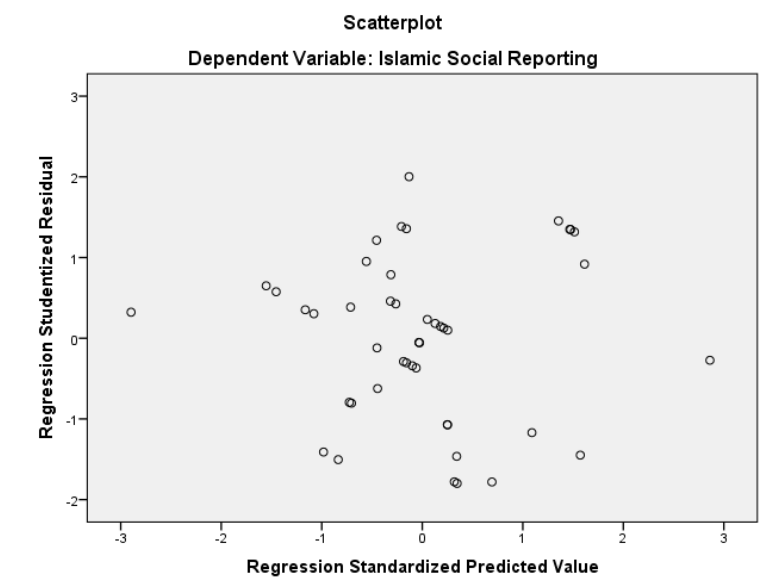

Sumber: data diolah

Gambar 3. Hasil Uji Heteroskedastisitas

\section{Hasil Analisis Regresi Linear Berganda}

Hasil uji regresi dapat dilihat di Tabel 3.

Tabel 3. Hasil Uji Regresi Berganda

\begin{tabular}{|c|c|c|c|c|c|c|}
\hline & & & Coeffici & ents ${ }^{a}$ & & \\
\hline & del & Unstanc & ardized & Standardiz & $\mathrm{t}$ & Sig. \\
\hline & & B & $\begin{array}{l}\text { Std. } \\
\text { Error }\end{array}$ & Beta & & \\
\hline & (Constant) & .513 & .059 & & 8.753 & .000 \\
\hline & Profitabilitas & -.001 & .001 & -.075 & -.400 & .691 \\
\hline 1 & Leverage & .000 & .000 & -.423 & -2.455 & .018 \\
\hline & $\begin{array}{l}\text { Kinerja } \\
\text { Lingkungan }\end{array}$ & .056 & .019. & .441. & 2.970 & 年. \\
\hline
\end{tabular}

a. Dependent Variable: Islamic Social Reporting

Sumber: data diolah

Berdasarkan hasil pengujian dengan metode regresi linier berganda di atas, ISR memiliki nilai konstanta sebesar 0,513. Hasil perhitungan itu menunjukkan bahwa apabila variabel-variabel independen konstan (tetap), maka nilai ISR adalah 0,513. Dan untuk menguji pengaruh variabel-variabel independent (ROA, DER, KL) terhadap variabel dependen (ISR) maka dapat disusun sebuah persamaan sebagai berikut:

$$
\mathrm{Y}=0.513-0.001 \mathrm{ROA}+0.000 \mathrm{DER}+0.056 \mathrm{KL}+\mathrm{e}
$$




\section{Hasil Uji Hipotesis}

\section{Hasil Uji Koefisien Determinasi}

Hasil uji koefisien determinasi $\left(\mathrm{R}^{2}\right)$ memperlihatkan nilai koefisien determinasi (Adjusted $R^{2}$ ) yang diperoleh sebesar 0,245 atau sebesar 24,5\%. Hal ini menunjukkan profitabilitas, leverage dan kinerja lingkungan berkontribusi sebesar 24,5\% terhadap besarnya pengungkapan ISR. Sedangkan sisanya sebesar 75,5\% dipengaruhi oleh variabel lain yang tidak diteliti dalam penelitian ini. Berikut tabel hasil pengujian koefisien determinasi:

Tabel 4. Hasil Uji Koefisien Determinasi

\begin{tabular}{|c|c|c|c|c|c|}
\hline \multicolumn{6}{|c|}{ Model Summary ${ }^{b}$} \\
\hline $\begin{array}{l}\text { Mode } \\
1\end{array}$ & $\mathrm{R}$ & $\begin{array}{c}\mathrm{R} \\
\text { Square }\end{array}$ & $\begin{array}{c}\text { Adjusted R } \\
\text { Square }\end{array}$ & $\begin{array}{l}\text { Std. Error of } \\
\text { the Estimate }\end{array}$ & Durbin-Watson \\
\hline 1 & $.544^{\mathrm{a}}$ & .296 & .245 & .06128 & 2.011 \\
\hline \multicolumn{6}{|c|}{ a. Predictors: (Constant), Kinerja Lingkungan, Leverage, Profitabilitas } \\
\hline \multicolumn{6}{|c|}{ b. Dependent Variable: Islamic Social Reporting } \\
\hline
\end{tabular}

\section{Hasil Uji Statistik F (Uji Simultan)}

Berdasarkan Tabel 5, dapat dilihat bahwa nilai signifikansi pada uji F sebesar 0,02 . Hal ini berarti nilai signifikansi pada uji F kurang dari $0,05(0,02<0,05)$. Oleh karena itu $\mathrm{H}_{1}$ diterima. Dengan demikian hipotesis yang diajukan penulis diterima berdasarkan hasil uji $\mathrm{F}$ dalam penelitian ini. Sehingga bisa dinyatakan bahwa model regresi tersebut signifikan secara simultan. Jadi, dapat disimpulkan bahwa variabel profitabilitas, leverage dan kinerja lingkungan secara bersama-sama berpengaruh signifikan terhadap pengungkapan ISR.

Tabel 5. Hasil Uji F

\begin{tabular}{lrrrrr}
\hline \multicolumn{5}{c}{ ANOVA $^{\mathrm{a}}$} & \\
\hline Model & $\begin{array}{c}\text { Sum of } \\
\text { Squares }\end{array}$ & $\mathrm{df}$ & $\begin{array}{c}\text { Mean } \\
\text { Square }\end{array}$ & $\mathrm{F}$ & Sig. \\
\hline Regression & .065 & 3 & .022 & 5.749 & $.002^{\mathrm{b}}$ \\
\hline Residual & .154 & 41 & .004 & & \\
\hline Total & .219 & 44 & & & \\
\hline
\end{tabular}

a. Dependent Variable: Islamic Social Reporting

b. Predictors: (Constant), Kinerja Lingkungan, Leverage,

Profitabilitas

Sumber: data diolah

\section{Hasil Uji Statistik $t$}

Hasil uji statistik $\mathrm{t}$ dapat dilihat pada Tabel 3, jika nilai probability $\mathrm{t}$ lebih kecil dari 0,05 maka $\mathrm{H}_{\mathrm{a}}$ diterima dan menolak $\mathrm{H}_{0}$, sedangkan jika nilai probability $\mathrm{t}$ lebih besar dari 0,05 maka $\mathrm{H}_{0}$ diterima dan menolak $\mathrm{H}_{\mathrm{a}}$. Tabel 3 di atas menunjukkan bahwa variabel leverage dan kinerja lingkungan mempunyai tingkat signifikasi 0,018 dan 0,005 hal ini berarti variabel leverage dan kinerja lingkungan berpengaruh secara 
signifikan terhadap pengungkapan ISR karena tingkat signifikansinya lebih kecil dari 0,05 sehingga dinyatakan hipotesis 2 dan hipotesis 3 diterima. Sedangkan profitabilitas mempunyai tingkat signifikasi 0,691 hal ini berarti variabel profitabilitas tidak berpengaruh secara signifikan terhadap pengungkapan ISR karena tingkat signifikansinya lebih besar dari 0,05 sehingga dinyatakan hipotesis 1 ditolak.

\section{Pembahasan}

\section{Pengaruh Profitabilitas terhadap Pengungkapan ISR}

Profitabilitas yang diproksikan oleh ROA memiliki nilai signifikansi sebesar 0,691 > taraf signifikansi 0,05. Berdasarkan hasil uji hipotesis menunjukkan bahwa profitabilitas tidak berpengaruh terhadap pengungkapan ISR. Dan menolak $\mathrm{H}_{2}$ yang menyatakan bahwa profitabilitas berpengaruh positif signifikan terhadap pengungkapan ISR.

Hal tersebut sesuai dengan hasil penelitian yang dilakukan oleh Rahayu (2018), Hartawati et al (2017), Dhiyaul-Haq dan Santoso (2016), Rosiana dkk. (2015), Faricha (2015), dan Astuti (2013), bahwa profitabilitas tidak mempengaruhi tingkat pengungkapan ISR. Dan bertolak belakang dengan hasil penelitian Anggraini dan Wulan (2015) dan Maulida dkk. (2014) yang menyatakan profitabilitas berpengaruh signifikan terhadap pengungkapan ISR.

Menurut Rahayu (2018), alasan yang mendasari hasil penelitian ini adalah dikarenakan adanya perusahaan yang mempunyai profitabilitas tinggi belum tentu banyak melakukan aktivitas sosial karena perusahaan lebih berorientasi pada laba semata. Sedangkan pada saat perusahaan memperoleh laba yang rendah, maka terdapat persepsi bahwa pengguna laporan senang untuk membaca berita baik tentang kinerja perusahaan dalam bidang sosial.

\section{Pengaruh Leverage terhadap Pengungkapan ISR}

Leverage yang diproksikan oleh DER memiliki nilai signifikansi sebesar 0,018 < taraf signifikansi 0,05. Berdasarkan uji hipotesis menunjukkan bahwa leverage berpengaruh positif dan signifikan terhadap pengungkapan ISR dan menerima $\mathrm{H}_{3}$ yang menyatakan bahwa leverage berpengaruh positif signifikan terhadap pengungkapan ISR.

Hasil penelitian ini tidak sejalan dengan penelitian sebelumnya yang dilakukan oleh Astuti (2013) yang menyatakan leverage tidak berpengaruh terhadap pengungkapan ISR. Dan sejalan dengan hasil penelitian yang dilakukan oleh Anggraini dan Wulan (2015), menyatakan bahwa leverage berpengaruh signifikan terhadap pengungkapan ISR.

Menurut Anggraini dan Wulan (2015), menyatakan bahwa perusahaan dengan leverage yang tinggi, akan cenderung lebih rendah dalam melakukan pengungkapan ISR. Hal ini mungkin disebabkan karena perusahaan yang memiliki banyak hutang, mereka tidak terlalu mementingkan pengungkapan tanggung jawab sosial. Mereka lebih mementingkan bagaimana hutang-hutang perusahaan mereka bisa berkurang seiring bertambahnya modal usaha mereka, selain itu juga mungkin akan muncul anggapan bahwa seharusnya perusahaan yang mengungkapkan tanggung jawab sosialnya dengan baik, rasio hutangnya seharusnya bisa lebih rendah. Sebaliknya, 
perusahaan dengan leverage yang rendah bisa mengungkapkan tanggung jawab sosialnya dengan baik, mungkin dikarenakan aset mereka yang lebih besar dan anggapan-anggapan yang muncul yang diatas sudah disebutkan.

\section{Pengaruh Kinerja Lingkungan terhadap Pengungkapan ISR}

Kinerja Lingkungan memiliki nilai signifikansi sebesar 0,005 < taraf signifikansi 0,05. Berdasarkan hasil uji hipotesis menunjukkan bahwa kinerja lingkungan berpengaruh positif dan signifikan terhadap pengungkapan ISR. Dan menerima $\mathrm{H}_{4}$ yang menyatakan bahwa kinerja lingkungan berpengaruh positif signifikan terhadap pengungkapan ISR.

Hasil penelitian ini konsisten dengan penelitian sebelumnya yang dilakukan oleh Maulida dkk. (2014) menyatakan bahwa kinerja lingkungan berpengaruh signifikan terhadap pengungkapan ISR. Dan inkonsisten dengan penelitian yang dilakukan oleh Rahayu (2018) dan Hartawati dkk. (2017) yang menyatakan bahwa kinerja lingkungan tidak memiliki pengaruh yang signifikan terhadap pengungkapan ISR.

Menurut Maulida dkk. (2014), menyatakan bahwa perusahaan yang melakukan atau mengungkapkan kinerja lingkungannya dapat menggambarkan perusahaan tersebut memiliki perilaku peduli lingkungan, dimana perusahaan dengan kinerja lingkungan yang tinggi akan mendapatkan nilai positif dalam pandangan masyarakat dan investor. Semakin banyaknya perusahaan yang sadar akan masalah lingkungan dengan keikutsertaan perusahaan dalam Program Penilaian Peringkat Kinerja Perusahaan dalam Pengelolaan Lingkungan Hidup (PROPER). Dengan keikutsertaan perusahaan dalam PROPER sendiri sudah memberikan pandangan positif kepada masyarakat, karena sudah mau memulai untuk peduli akan masalah lingkungan, dan dampak perusahaan terhadap lingkungan.

\section{SIMPULAN}

Berdasarkan hasil penelitian ini dapat disimpulkan bahwa hasil uji F simultan seluruh variabel independen baik profitabilitas, leverage, dan kinerja lingkungan berpengaruh signifikan secara simultan terhadap pengungkapan Islamic Social Reporting (ISR). Dengan nilai Adjusted $R$ Square yang didapat dari hasil uji koefisien determinasi sebesar 0,245 atau 24,5\%. Hal ini menunjukkan bahwa besar persentase variasi Islamic Social Reporting yang bisa dijelaskan oleh variasi ketiga variabel bebas yaitu profitabilitas, leverage dan kinerja lingkungan sebesar $24,5 \%$, sedangkan sisanya 75,5\% dijelaskan oleh variabel-variabel lain diluar penelitian ini.

Hasil penelitian ini memberikan hasil empiris bahwa, pertama, profitabilitas perusahaan yang dihitung dengan ROA tidak memiliki pengaruh terhadap pengungkapan Islamic Social Reporting (ISR). Karena dalam pandangan Islam perusahaan yang memiliki niat untuk melakukan pengungkapan penuh tidak akan mempertimbangkan apakah perusahaan tersebut untung atau rugi.

Kedua, bahwa leverage perusahaan yang diproksikan oleh DER memiliki pengaruh positif dan signifikan terhadap pengungkapan Islamic Social Reporting (ISR). Hal ini membuktikan bahwa besar kecilnya utang yang digunakan oleh perusahaan 
di JII untuk membiayai operasional usaha memberikan dampak terhadap besar kecilnya pengungkapan ISR. Hal ini juga menandakan bahwa pengungkapan tanggung jawab sosial secara syariah pada perusahaan yang terdaftar di JII telah menjadi suatu kewajiban baik dalam kondisi leverage rendah maupun tinggi.

Ketiga, bahwa kinerja lingkungan yang dilakukan oleh perusahaan memiliki pengaruh positif dan signifikan terhadap pengungkapan Islamic Social Reporting (ISR). Dengan keikutsertaan perusahaan dalam PROPER memberikan pandangan positif kepada masyarakat, karena perusahaan sudah memiliki kepedulian terhadap masalah lingkungan dan memperhatikan dampak operasional perusahaan terhadap lingkungan. Kinerja lingkungan perusahaan yang cukup baik akan memberikan persepsi yang cukup baik pula terhadap keberadaan dan eksistensi perusahaan dalam pandangan investor maupun masyarakat.

Dalam penelitian ini terdapat beberapa keterbatasan yang sebaiknya perlu dilakukan perbaikan dalam penelitian-penelitian lebih lanjut. Adapun keterbatasan dalam penelitian ini dan saran untuk penelitian selanjutnya adalah 1) adanya subjektifitas penulis dalam menentukan dan mengidentifikasi pengungkapan indeks ISR. Hal ini karena tidak adanya ketentuan baku yang dapat dijadikan acuan sehingga penentuan indeks untuk indikator dalam kategori yang sama dapat berbeda untuk setiap peneliti. 2) Pemilihan variabel independen dalam penelitian ini hanya dilihat dari tiga variabel saja, penelitian selanjutnya disarankan untuk menambah variabel independen lain yang mungkin dapat mempengaruhi pengungkapan ISR seperti ukuran perusahaan, umur perusahaan, jenis atau tipe industri, komposisi dewan direksi atau komisaris dan variabel independen lainnya. 3) Jumlah sampel perusahaan yang digunakan dalam penelitian ini masih terlalu sedikit, yaitu 9 perusahaan yang terdaftar di JII. Saran untuk penelitian selanjutnya adalah memperluas jumlah sampel perusahaan dengan menggunakan perusahaan yang ada di Daftar Efek Syariah (DES) atau Indeks Saham Syariah Indonesia (ISSI).

\section{DAFTAR PUSTAKA}

Anggraini, A., dan Wulan, M. (2015). Faktor Financial-NonFinancial Dan Tingkat Pengungkapan Islamic Social Reporting (ISR). Jurnal Akuntansi Dan Keuangan Islam, 3(2), 161-184.

Astuti, T. (2013). Pengaruh Profitabilitas, Likuiditas dan Leverage terhadap Pengungkapan Islamic Social Reporting (Studi Empiris pada Perusahaan yang Terdaftar di JII Tahun 2010-2012), 1-20. Artikel. https://www.iqtishadconsulting.com/assets/media/file/file-pengaruhprofitabilitas-likuiditas-dan-leverage-terhadap-pengungkapan-islamic-socialreporting-studi-empiris-pada-perusahaan-yang-terdaftar-di-jii-tahun-20102012.pdf (Diakses tanggal 20 Oktober 2018).

Deegan, C. 2000. Financial Accounting Theory. NSW: McGraw-Hill Australia. 
Dhiyaul-haq, Z. M., dan Santoso, A. L. (2016). Pengaruh Profitabilitas, Penghargaan, dan Tipe Kepemilikan Bank Umum Syariah Terhadap Pengungkapan Islamic Social Reporting. Simposium Nasional Akuntansi XIX, Lampung, 1-27.

Faricha, N. (2015). Analisis Faktor - Faktor yang Mempengaruhi Islamic Social Reporting pada Perusahaan Pertambangan yang Terdaftar dalam Indeks Saham Syariah Indonesia (ISSI) tahun 2011 - 2014. British Journal of Psychiatry, (01), 7677.

Ghozali, Imam. 2012. Aplikasi Analisis Multivariate dengan Program IBM SPSS 20. Semarang: Penerbit UNDIP.

Hartawati, E., Sulindawati, N. L. G. E., dan Kurniawan, P. S. (2017). Kinerja Sosial, Kinerja Lingkungan dan Komite Audit Terhadap Pengungkapan Islamic Social Reporting (ISR) pada Perusahaan yang Terdaftar di Jakarta Islamic Index ( JII ) Periode Tahun 2014-2016. E-Journal S1 Ak Universitas Pendidikan Ganesha, 8(2).

https://idx.co.id. Diakses tanggal 28 Oktober 2018

https:/ / menlh.go.id. Diakses tanggal 28 Oktober 2018

https:/ / proper.menlh.go.id. Diakses tanggal 28 Oktober 2018

Maulida, A. P., Yulianto, A., dan Asrori. (2014). Analisa Faktor-Faktor yang Mempengaruhi Pengungkapan Islamic Social Reporting (ISR). Simposium Nasional Akuntansi XVII Lombok, 39(5), 561-563.

Rahayu, T. P. (2018). Analisis Faktor-Faktor yang Mempengaruhi Pengungkapan Islamic Social Reporting pada Perusahaan yang Terdaftar di Jakarta Islamic Index Periode 2010-2013. E-Journal Ekonomi Bisnis Dan Akuntansi, 2(2), 109-114.

Rosiana, R., Arifin, B., dan Hamdani, M. (2015). Pengaruh Ukuran Perusahaan, Profitabilitas, Leverage, Dan Islamic Governance Score Terhadap Pengungkapan Islamic Social Reporting (Studi Empiris Pada Bank Umum Syariah di Indonesia Tahun 2010-2012). ESENSI Jurnal Bisnis Dan Manajemen, 5(1), 87-104. 
Nawang Kalbuana, Marista W. Sutadipraja, Titik Purwanti, \& Dwi Santoso

Halaman ini sengaja dikosongkan 